\title{
Discretionary Power on the Front Line A Bottom-up Perspective on Corporate Language Management
}

\author{
Sanden, Guro Refsum; Lønsmann, Dorte
}

Document Version

Accepted author manuscript

Published in:

European Journal of International Management

DOI:

10.1504/EJIM.2018.10009388

Publication date:

2018

License

Unspecified

Citation for published version (APA):

Sanden, G. R., \& Lønsmann, D. (2018). Discretionary Power on the Front Line: A Bottom-up Perspective on Corporate Language Management. European Journal of International Management, 12(1-2), 111-137. https://doi.org/10.1504/EJIM.2018.10009388

Link to publication in CBS Research Portal

\section{General rights}

Copyright and moral rights for the publications made accessible in the public portal are retained by the authors and/or other copyright owners and it is a condition of accessing publications that users recognise and abide by the legal requirements associated with these rights.

Take down policy

If you believe that this document breaches copyright please contact us (research.lib@cbs.dk) providing details, and we will remove access to the work immediately and investigate your claim. 


\title{
Discretionary Power on the Front Line: A Bottom-up Perspective on Corporate Language Management
}

\section{Guro Refsum Sanden and Dorte Lonsmann}

\author{
Journal article (Accepted manuscript*)
}

\section{Please cite this article as:}

Sanden, G. R., \& Lonsmann, D. (2018). Discretionary Power on the Front Line: A Bottom-up Perspective on Corporate Language Management. European Journal of International Management, 12(1-2), 111-137. 00:

10.1504/EJIM.2018.089042

DOI: 10.1504/EJIM.2018.089042

* This version of the article has been accepted for publication and undergone full peer review but has not been through the copyediting, typesetting, pagination and proofreading process, which may lead to differences between this version and the publisher's final version AKA Version of Record.

Uploaded to CBS Research Portal: May २०19 


\title{
Discretionary power on the front-line: A bottom-up perspective on corporate language management
}

\author{
Guro R. Sanden and Dorte Lønsmann \\ Copenhagen Business School \\ Department of Management, Society and Communication \\ Dalgas Have 15 \\ DK-2000 Frederiksberg \\ Denmark \\ Email: grs.msc@cbs.dk \\ Email: $\underline{\text { dl.msc@ecbs.dk }}$
}

\begin{abstract}
This article investigates the communication practices used by front-line employees to cross language boundaries in the context of English language policies implemented by the management of three multinational corporations (MNCs) headquartered in Scandinavia. Based on an analysis of interview and document data, our findings show that employees face a number of different language boundaries in their everyday work, and that ad hoc and informal solutions in many cases are vital for successful cross-language communication. We introduce the concept of 'discretionary power' to explain how and why front-line employees diverge from the corporate language policies, and emphasise the role of individual agency in the implementation of language policy. With a focus on the communication practices of frontline employees, the article contributes with a bottom-up, employee-centred perspective on corporate language management, emphasising the importance of paying attention to the micro level of everyday interactions in the study of language policy and practice.
\end{abstract}




\section{Keywords}

English as a corporate language, discretionary power, linguistic diversity, language policy, front-line, employee perspective

\section{Biographical notes:}

Guro Refsum Sanden is a Postdoctoral Researcher at the Department of Management, Society and Communication at Copenhagen Business School and a visiting scholar at the SCANCOR/Weatherhead Initiative at Harvard University. Her research focuses on the role of corporate language strategies in multinational corporations and the relationship between national language policies and corporate law. Before entering academia, she held various industry positions, including management trainee in the Danish insurance company Tryg. Her work has been published in outlets such as Applied Linguistics, Corporate Communications and $A I B$ Insights.

Dorte Lønsmann is Associate Professor at the Department of Management, Society and Communication at Copenhagen Business School. Her research is based in the fields of anthropological linguistics and qualitative sociolinguistics. The focus of her current research is multilingualism in the workplace, including language practices among blue-collar workers, language socialization, the implementation of corporate language policies and social categorisation and social exclusion in linguistically diverse workplaces. Her work has been published in journals such as Multilingua, Journal of Multilingual and Multicultural Development and International Journal of Cross Cultural Management.

\section{Introduction}

Increasing internationalisation of business organisations frequently entails increased linguistic diversity. This diversity may be viewed as a barrier for corporate communication and cohesion. For this reason, companies may choose to implement language policies that introduce a common corporate language for company-wide communication or for specific units within the organisation (e.g. Duchêne, 2009; Piekkari, Welch, and Welch, 2014). Such corporate language policies frequently favour English (Angouri and Miglbauer, 2014; Lønsmann, 2014). However, previous studies indicate that the relationship between language 
policies developed at management level and language practices at the front-line level may be more complex than the company's leadership had expected or planned for (Fredriksson, Barner-Rasmussen, and Piekkari, 2006; Vaara et al., 2005). Such discrepancies between de facto and de jure language policies suggest that studies of corporate language policies need to focus on the implementation of language policies, and further that they need to take the perspective of the company's employees and focus on their role in the implementation process.

In previous research on the implications of introducing new corporate language policies (Marschan-Piekkari, Welch and Welch, 1999a), focus has been on managers (Neeley, 2013; Vaara et al., 2005) and/or on managerial implications (Harzing and Feely, 2008; Harzing and Pudelko, 2013; Marschan-Piekkari, Welch and Welch, 1999b). Focus has been mainly on improving communication in MNCs and other organisations, with language policies seen as the means to solve communication problems (e.g. Neeley, Hinds and Cramton, 2012). By advocating the importance of individual language use in the context of corporate language management we depart from much of the existing research on the role of language in international business (see Björkman, Barner-Rasmussen and Vaara, 2010). Instead we wish to focus on employees' communicative practices and investigate how employees handle linguistic diversity in their daily work. Based on qualitative data from three MNCs headquartered in Scandinavia, the article examines the ways in which front-line employees cross language boundaries in their everyday work.

The companies we investigate all have English language policies, and as such the employees do not operate in a vacuum when they handle linguistic diversity. Our focus on employees' communication practices implies recognition of the role of individual agency in policy implementation processes. In our case the agency exercised by individual front-line employees in crossing language boundaries is constrained by the structures in place in the form of organisational culture, including the language policy. By exploring the practices used by front-line employees against the backdrop of the structure put in place by the corporate language policies in the three companies, the study positions itself within work that explores the dialectic of structure and agency (Giddens, 1991), specifically in relation to language choice in MNCs (Gaibrois, 2015). We do so by drawing on the concept of 'discretionary power' (Lipsky, 1980, 2010), i.e. the power employees have to make a choice among possible courses of action and inaction (Davis, 1969). As such the study contributes to the international 
management literature with the employee perspective on the interplay between language policy and practice. Furthermore, by focusing on concrete communication practices, the study also contributes with a micro-level perspective that is often overlooked in favour of meso or macro level studies of management and strategy.

\section{Language policies and practices in MNCs}

A language policy that favours one or a small number of languages over others may have significant power implications for individuals in a multilingual organisation (Lønsmann, 2014; Marschan-Piekkari et al., 1999a; Neeley, 2013). In non-native English-speaking countries, an English language policy will restrict the ability of most employees to use their mother tongue. Boussebaa, Sinha and Gabriel's (2014) study on the use of English in Indian call centres draws attention to how 'Englishization' reproduces colonial-style power relations in the global economy, as the use of English often is a requirement for establishing partnerships with Anglo-American firms. Findings from these offshore outsourcing organisations reveal the formation of language-based hierarchies where employees' position in the hierarchy derives from their ability to speak in the preferred English accent of the client. Front-line operatives and aspirants without appropriate language and communication skills are designated to the lower levels of the hierarchy with feeble possibilities to advance in the organisation. Similar tendencies have been observed also in other industries, for example in non-native English-speaking academic communities, as reported by Boussebaa and Brown (2016) and Tietze and Dick (2012).

Although the importance of English language skills is undisputed in these studies, the ability to communicate in other languages may be equally important, for example Scandinavian languages in Scandinavia. Vaara et al. (2005) examine language policy choices and their effects in a merging financial services company in Sweden and Finland. They find that the decision to implement Swedish as the official corporate language in the new merged organisation empowered the Swedish-speaking employees, while the Finnish-speaking employees were disempowered and constrained by the language policy. Vaara et al. conclude that language skills are both empowering and disempowering resources at the level of episodic social interaction. Furthermore, they show how discussions around language in the organisation reproduced post-colonial identities and positions of superiority and inferiority. Ultimately, the discussions around language policy decisions contributed to legitimizing neo- 
colonial corporate control. Vaara et al.'s analysis highlights the central role of the interpretations and actions of the 'powerless' in enacting the power relationships constructed by the language policy. They find that 'resistance' and 'coping' strategies of employees not proficient in the official corporate language contributed to their own subordination (2005, p. 620), e.g. in cases where employees sought new positions within the organisation where they could avoid the corporate language, or where they decided to leave the organisation altogether.

The above studies confirm that language policy decisions from the top have implications for employees in the form of decreased status and power in the organisation and sometimes even in the form of hampering professional mobility and changing career trajectories. The current study's interest in employees' communicative practices is related to these studies in that it also investigates how power is related to top-down language management, but at a more micro level and with a focus on employee agency. We want to take the analysis to the front-line, to the offices and the desks of employees and look at how they cope with language barriers in their everyday work, and how they use their discretionary power in the face of top-down language mandates.

So far no systematic analyses have been conducted of employees' use of discretionary power to overcome language boundaries. However, previous work in the language-sensitive research stream in international business (Piekkari and Tietze, 2011) suggests that these frontline communication practices deserve more attention. A recent study finds that managers tend to underestimate the importance of language differences, whereas issues related to institutional, legal or geographic distance are given a higher priority (Harzing and Pudelko, 2014). This stance may result in a decentralised language policy where the issue of communication is pushed down the hierarchy, out of sight of top management (Welch, Welch, and Piekkari, 2001). In such situations, employees at the front-line are the ones that have to deal with everyday issues of language and communication (Andersen and Rasmussen, 2004). Even in cases with an established language policy, employees may have to resort to ad hoc solutions to deal with a language issue on the spot, as found in Piekkari et al.'s (2013) study of a corporate translation department where employees often chose self-translation or consulted their network rather than making use of the company's translation services.

Harzing, Köster, and Magner (2011) find that employees adjust the communication mode, e.g. by using email instead of phone calls. Charles and Marschan-Piekkari (2002), 
Harzing et al. (2011) and Shachaf (2008) discuss how the choice of a written communication medium may improve efficiency compared with an oral communication medium, as different speech varieties and accents may cause comprehension problems. Lønsmann (2011) finds that ad hoc and informal help from colleagues is the most important resource in overcoming language barriers, and likewise Tietze (2010) shows how language-skilled employees may take it upon themselves to help colleagues in need of language assistance.

Another way of dealing with language barriers is to withdraw from the interaction. As noted by Piekkari et al. (2014, pp. 55-58), avoidance behaviour can be seen as a type of filtering system where information is either passively ignored or actively evaded by individuals. This practice is frequently linked with a lack of competence in the corporate language. Neeley's (2013) study of French managers working in a company with English as a corporate language finds that low and medium-fluency speakers are either silent in meetings with native speakers or stay away from the meetings altogether because they do not want to get into discussions where they will have to elaborate in English, or because they are afraid of 'looking silly' (2013, p. 14). Similarly, Śliwa and Johansson (2014) find evidence of avoidance when non-native English-speaking employees refrain from active participation in meetings because of fear that their accent will lead others to deeming them less intelligent.

Finally, Lauring and Klitmøller (2015) find that employees in Danish MNCs with English as a corporate language tend to avoid the use of the corporate language more in informal communication than in formal work situations, and that some employees avoid speaking English in larger groups. Power is also an issue in their study where employees are more likely to avoid communicating in English with higher status interlocutors, e.g. managers, since they become more aware of their language deficiencies and thus more stressed in those situations.

With Sanden (2015, p. 41) we conceptualise such ad hoc and informal communication practices as 'front-line communication practices', i.e. informal tools and changes in communication practices that employees draw on in response to emergent language needs. Such front-line communication practices are implemented at the front-line level without a corporate level 'language manager' (Spolsky, 2009). Unlike corporate level language management initiatives, front-line communication practices are employees' self-initiated reactions to the language needs they encounter in linguistically diverse work environments. We define 'front-line employees' as employees who have to cross language barriers in their 
daily work either in company internal communication or in communication with customers, but who do not have a role in language policy making.

\section{The discretionary power of the front-line employee}

Following Vaara et al. (2005) we see language skills as potentially empowering or disempowering resources in everyday social interaction. Specifically we want to focus on how employees use their communication skills, including multilingual competences, in these everyday interactions. We are particularly interested in how the organisational power invested in a corporate language policy interacts with the discretionary power of front-line employees. The concept of discretionary power, as developed by Lipsky $(1980,2010)$ refers in the original context of street-level bureaucracy theory to the often improvised strategies workers resort to in order to manage their jobs. Gilson (2015) finds that front-line workers do not deliberately work to oppose policy aims, but use their discretionary power when policies are incompatible with their work lives. It is this tension between a top-down policy and the onthe-ground realities of crossing language boundaries we aim to capture by introducing the notion of discretionary power into the study of language policy and practice in international organisations.

By focusing on the discretionary power of employees, we give emphasis to what has been called the positive or constructive aspects of power, in the form of "individual agency, [and] the creation of possibilities" (Gaibrois, 2015, p. 47). Drawing on Foucault for her conceptualization of agency, Gaibrois (2015, p. 49) argues that the emphasis on agency is particularly appropriate for investigating how employees of multilingual organizations without language policies negotiate language use. It is also, we would argue, an emphasis that is very appropriate for investigating how employees negotiate language use in organisations where a language policy does form part of the organisational structure.

Relying on the notion of employees' discretionary power allows us to combine a focus on agency and the creation of possibilities for communication with an understanding of the organisational context. Previous studies of discretionary power reveal that the influence of the organisational context is crucial for understanding the practices of front-line employees. Rather than being primarily a response to personal preferences and interests, the solutions employees resort to are often the result of organisational pressures, such as a heavy workload and time constraints (Hughes and Condon, 2016; Meyers and Vorsanger, 2007). Frequently, 
front-line employees do not deliberately work to oppose policy aims, but use their discretionary power when policies are incompatible with their work lives (Gilson, 2015; Sevä and Jagers, 2013). Durose (2009) describes front-line employees as situated agents who rely upon their local knowledge to develop responsive solutions in response to various and sometimes conflicting demands. These findings underline the fact that front-line communication practices are constructed and negotiated in the interplay between individual agency and institutional structures, i.e. the policy and the working conditions in the specific organisation. We conceptualise this interplay here as front-line employees' discretionary power, i.e. their power to act within and across the frames and expectations set up by the language policy. This leads us to the following research question: How do front-line employees use their discretionary power to cross language boundaries in MNCs with topdown English language mandates? By answering this question we aim to contribute to the theory development within studies of corporate language management by detailing how and why front-line employees diverge from the corporate language policies, and by discussing the role of individual agency in the implementation of language policy.

\section{Methodology}

Our data come from two qualitative studies of language policy and practice in MNCs headquartered in Denmark and Sweden. Scandinavia is a non-Anglophone region of the world where the use of English language policies has become widespread for internationalising companies. A survey conducted by the Confederation of Danish Industry in 2013 among 230 of their member organisations found that $53 \%$ of these companies (122) made use of English as a corporate language (Confederation of Danish Industry, 2013). The Scandinavian languages are spoken by relatively small populations, which may explain why firms with international aspirations find it necessary to adopt English language mandates (Piekkari et al., 2014, pp.14-22).

We have conducted interviews in three companies to investigate the range of front-lines communication practices employees make use of to cross language boundaries. Drawing on data from two separate research projects originally conceived for different purposes means that two types of interviews were used. The first study (of Mancorp ${ }^{1}$ and Bankcorp) used individual, semi-structured interviews, while the second study (of Consult) used focus group

\footnotetext{
${ }^{1}$ All names, including people and companies, are pseudonyms.
} 
interviews, which unlike individual interviews also offer access to interaction between informants. However, we view all interview data as constructed in interaction between researcher and informants (cf. Sayer, 1992). Our interviews are carried out with the purpose of identifying how respondents manage language-boundary crossing in their multilingual work life, and in particular why they choose these practices seen in relation to the company's top-down language management (Sanden, 2016). We therefore give emphasis to the setting in which these front-line communication practices take place by seeking a contextualised explanation (Welch et al., 2011) of individual language behaviour (see also Maxwell, 2012).

The interviews were carried out in a Scandinavian language or in English, according to the preference of our interviewees. A list of all informants is included in Appendix I, which also contains information about the interview language and informants' mother tongues. Due to limited space, the present article only includes the English translations of our Scandinavian interview data, which were translated by the authors. The original Scandinavian quotes are available in Appendix II.

In each of the three companies we interviewed between 10 and 15 informants, who were identified by a snowballing/chain sampling strategy (Patton, 2002). The interviews covered a range of topics related to language use at work, including solutions for crossing language boundaries. We interviewed front-line employees about their normal language and communication practices and how the company's language policy affects their daily worklife. These role informants (Walker and Enticott, 2004) included employees in occupational positions such as consultant and project manager. We also interviewed key informants (Kumar, Stern, and Anderson, 1993), such as managers and employees working directly with language or communication.

The fact that the present study relies on interview data means that we only have data on reported practice - i.e. the informants' own account of how and in what language they communicate - and no access to actual language and communication practices. Reported practices can constitute a method bias if these are not consistent with actual practices, but the bias may be reduced by asking follow-up questions during the interview (Björkman, BarnerRasmussen and Li, 2004, p. 453). Comparing interview data from different informants is also a way of limiting the risk of inaccuracy, thus improving the credibility of the data (Symon and Cassell, 2012, p. 212). Both strategies were adopted in the current study. Consistent with the theoretical notion of discretionary power, we pay particular attention to how front-line 
employees respond to language policies in terms of their everyday practices, and whether their responses are consistent with the official language policy statements of the company. We are interested in how individual behaviour is influenced by the organisational context, and we believe that the interview setting offers a constructive forum for asking clarifying questions, thereby gaining deeper insight into the reasons why individuals make the language choices that they do. In this way we give prominence to individual actions and human agency by acknowledging the stories that are being told by front-line employees (cf. Durose, 2009).

In addition to the interviews, we also use language policy documents and other documentation from the organisations to investigate how practices are related to top-down language management. A list of the documents is attached in Appendix 1. A summary of the three companies and the collected data is presented in Table 1.

\begin{tabular}{|c|c|c|c|}
\hline & Mancorp & Bankcorp & Consult \\
\hline Description & $\begin{array}{l}\text { World leading } \\
\text { manufacturer of } \\
\text { pumps }\end{array}$ & Leading Nordic bank & $\begin{array}{l}\text { Leading Nordic } \\
\text { engineering and } \\
\text { consultancy company }\end{array}$ \\
\hline Year founded & 1945 & 2000 & 1945 \\
\hline $\begin{array}{l}\text { Number of } \\
\text { employees, } 2013\end{array}$ & 19,000 & 30,000 & 10,000 \\
\hline $\begin{array}{l}\text { Revenue in } 2013, \\
\text { EURm }\end{array}$ & 3100 & 1000 & 1050 \\
\hline $\begin{array}{l}\text { Present in number of } \\
\text { countries, } 2013\end{array}$ & 55 & 19 & 35 \\
\hline Home country & Denmark & Sweden & Denmark \\
\hline $\begin{array}{l}\text { Corporate language } \\
\text { policy }\end{array}$ & $\begin{array}{l}\text { Formalised language } \\
\text { policy implemented } \\
\text { in } 2002 \text {. Common } \\
\text { corporate language } \\
\text { British English + use } \\
\text { of local language (not } \\
\text { specified). }\end{array}$ & $\begin{array}{l}\text { Formalised language } \\
\text { policy implemented } \\
\text { in } 2000 \text {. Common } \\
\text { corporate language } \\
\text { British English + use } \\
\text { of Swedish, } \\
\text { Norwegian, Danish, } \\
\text { Finnish. }\end{array}$ & $\begin{array}{l}\text { Formalised language } \\
\text { policy implemented } \\
\text { in Danish part of the } \\
\text { organisation in } 2014 . \\
\text { English as the } \\
\text { common corporate } \\
\text { language }+ \text { use of } \\
\text { local languages. }\end{array}$ \\
\hline $\begin{array}{l}\text { In-house translation } \\
\text { department }\end{array}$ & $\begin{array}{l}\text { Yes, for external } \\
\text { communication }\end{array}$ & $\begin{array}{l}\text { Yes, for internal and } \\
\text { external } \\
\text { communication }\end{array}$ & No \\
\hline
\end{tabular}




\begin{tabular}{|c|c|c|c|}
\hline $\begin{array}{l}\text { Data } \\
\text { (see Appendix for } \\
\text { overview of } \\
\text { informants and } \\
\text { document data) }\end{array}$ & $\begin{array}{l}12 \text { semi-structured } \\
\text { individual interviews, } \\
\text { between } 35 \text { and } 60 \\
\text { minutes. } \\
\text { Document data. }\end{array}$ & $\begin{array}{l}10 \text { semi-structured } \\
\text { individual } \\
\text { interviews, between } \\
35 \text { and } 90 \text { minutes. } \\
\text { Document data. }\end{array}$ & $\begin{array}{l}3 \text { focus groups with } \\
\text { each } 5 \text { employees, } \\
\text { between } 90 \text { and } 120 \\
\text { minutes. } \\
\text { Document data. }\end{array}$ \\
\hline
\end{tabular}

Table 1 Summary of companies and data

The transcribed interviews and the documents were analysed using a methodology inspired by Corbin and Strauss' $(1990,2008)$ basic principles for coding of qualitative data, distinguishing between different hierarchical levels of codes. The data were first coded according to company (level 1). Subsequently, a cross-company analysis led to the level 2 codes presented in Table 2 below, through which the codes emerged both from the data itself (commonly referred to 'in vivo' codes, cf. Strauss and Corbin, 1998), and from previous theory. The codes that derived from the data through inductive reasoning were based on reappearing or common responses across the interview data. In addition to the 'in vivo' codes, level 2 codes were also developed based on knowledge generated from the existing literature, also commonly referred to as 'a priori codes' (Patton, 2002; Strauss, 1987). These theoretical nodes emerged on the basis of deductive reasoning, as we were guided by the literature when analysing the data. Finally, a number of codes were developed based on the semi-structured interview guides and specific interview questions, for example in relation to the company's language policy, thereby paying particular attention to the specific company context (cf. Welch et al., 2011). After the first round of level 2 coding, all codes were carefully reviewed and clustered together according to common topics. This was part of a process that Corbin and Strauss (1990, p. 14) refer to as 'selective coding', in which codes that are thematically close are unified under a common category to form the level 3 codes (Corbin and Strauss; 1990; Corley and Gioia, 2004).

The data material was analysed in two separate data analysis processes, as the data itself had been gathered in two rounds of data collection (the first author gathered data in Bankcorp and Mancorp, while the second author collected data in Consult). When we brought the two analyses together, it resulted in a revised coding system where we introduced a new level of codes (level 4), and merged and adjusted codes that seemed overlapping or redundant. An overview of our final coding system is presented in Table 2 . The quotes presented in the 
analysis section have been selected because of their representativeness of the corpus as a whole.

\begin{tabular}{|c|c|c|c|c|}
\hline Level 4 & Level 3 & Level 2 & Description & Example \\
\hline \multirow[t]{5}{*}{$\begin{array}{l}\text { Crossing } \\
\text { language } \\
\text { boundaries }\end{array}$} & \multirow[t]{2}{*}{$\begin{array}{l}\text { Adjusting } \\
\text { communic } \\
\text { ation }\end{array}$} & $\begin{array}{l}\text { Communica } \\
\text { tion } \\
\text { accommoda } \\
\text { tion }\end{array}$ & $\begin{array}{l}\text { Informants adjust } \\
\text { their accent, speed or } \\
\text { vocabulary to } \\
\text { improve } \\
\text { communication }\end{array}$ & $\begin{array}{l}\text { Americans need to [...] } \\
\text { speak with an American } \\
\text { accent we are able to } \\
\text { understand. }\end{array}$ \\
\hline & & $\begin{array}{l}\text { Adjusting } \\
\text { communicat } \\
\text { ion mode }\end{array}$ & $\begin{array}{l}\text { Informants adjust } \\
\text { their mode of } \\
\text { communication } \\
\text { (oral, written or } \\
\text { visual) to improve } \\
\text { communication }\end{array}$ & $\begin{array}{l}\text { Most of the communication } \\
\text { has to be via emails, } \\
\text { because we have to refer to } \\
\text { what we have agreed. }\end{array}$ \\
\hline & \multirow[t]{3}{*}{$\begin{array}{l}\text { Finding } \\
\text { help }\end{array}$} & $\begin{array}{l}\text { Language } \\
\text { tools }\end{array}$ & $\begin{array}{l}\text { Informants seek help } \\
\text { in company-internal } \\
\text { or company-external } \\
\text { language tools }\end{array}$ & $\begin{array}{l}\text { Bankcorp terms is our own } \\
\text { term database. }\end{array}$ \\
\hline & & Translation & $\begin{array}{l}\text { Informants seek help } \\
\text { from in-house } \\
\text { translation } \\
\text { department }\end{array}$ & $\begin{array}{l}\text { I write the article in English, } \\
\text { send it for proofreading in } \\
\text { the translation department, } \\
\text { who then take care of the } \\
\text { translation }\end{array}$ \\
\hline & & $\begin{array}{l}\text { Collegial } \\
\text { language } \\
\text { help }\end{array}$ & $\begin{array}{l}\text { Informants seek help } \\
\text { from colleagues }\end{array}$ & $\begin{array}{l}\text { We know who are good at } \\
\text { English, so we can draw on } \\
\text { them. }\end{array}$ \\
\hline \multirow[t]{2}{*}{$\begin{array}{l}\text { Avoiding } \\
\text { language } \\
\text { boundaries }\end{array}$} & \multicolumn{2}{|c|}{$\begin{array}{l}\text { Avoiding oral } \\
\text { communication }\end{array}$} & $\begin{array}{l}\text { Informants avoid or } \\
\text { participate less in } \\
\text { meetings or other } \\
\text { forms of oral } \\
\text { communication }\end{array}$ & But you hold back, you do. \\
\hline & \multicolumn{2}{|c|}{$\begin{array}{l}\text { Avoiding written } \\
\text { communication }\end{array}$} & $\begin{array}{l}\text { Informants ignore or } \\
\text { delete emails or } \\
\text { other written } \\
\text { communication }\end{array}$ & $\begin{array}{l}\text { Those things in English, you } \\
\text { um weed out more quickly } \\
\text { because it may be less } \\
\text { comprehensible. }\end{array}$ \\
\hline
\end{tabular}

Table 2 The coding system

\section{Research setting: English in Scandinavian business}

Our three companies are all multinational corporations headquartered in Scandinavia. The local languages Danish, Norwegian and Swedish are the majority languages in Denmark, 
Norway and Sweden respectively, and the three languages are to some degree mutually intelligible. In fact, a recent study of language ideologies among Danish managers shows that the use of receptive multilingualism is preferred among Scandinavians and even constructed as the only natural choice (Kraft and Lønsmann fc.). However, English holds a privileged position in corporate settings as the preferred lingua franca for cross-border communication (Lønsmann, 2015).

Mancorp, Bankcorp and Consult have all chosen to adopt English language policies. Mancorp implemented English as their common corporate language in 2002, which is evident in the company's language policy document stating that 'Being an international group of companies Mancorp needs a shared corporate language, and this shared language is British English.' At the same time, the policy also allows for the use of various local languages in country-based communication. A similar distinction between cross-border and country-based communication can be found in Bankcorp's language policy from 2000. This language policy was implemented when Bankcorp was coined as a cross-border merger of independent banks across the Nordic region. Bankcorp's language policy text is available in five languages English, Swedish, Norwegian, Danish, and Finnish - and states in the English version that: 'Our corporate language is English (British English). This is the language we use in crossborder communication. Local communication - external customer communication as well as internal communication - can be executed in the respective local language.'

In contrast with these corporate level language policies, Consult's language policy only covers the Danish part of the organisation, Consult DK. Also here, however, is English constructed as the language used to cross borders: English is 'the language we use to communicate with our colleagues who do not speak the same language as we do'. The policy also states that Consult works with the concept of 'parallel languages' which means that English 'goes hand-in-hand' with other languages spoken by Consult employees. Rather than focusing on setting (global vs. local), the Consult language policy emphasises that language choice should depend on 'the situation and the people with whom you communicate'. Apart from this one mention of parallel languages, the rest of the policy focuses on the increased use of English in the organisation.

\section{Results: Front-line communication practices under English language policies}


This section presents the results of the analysis and aims to answer the question: How do front-line employees use their discretionary power to cross language boundaries in MNCs with top-down English language mandates? The results in the following section are organised according to the outcome of the coding process with the first part discussing practices used for crossing language boundaries, followed by a section discussing the practice of avoiding language boundaries. As such the analysis also presents examples in an order from practices aligned with the corporate language policies to practices where employees increasingly use their discretionary power.

\section{Crossing language boundaries}

\section{Communication accommodation}

Successful language-boundary crossing may require interlocutors to make certain linguistic accommodations (Giles and Coupland, 1991) in order to get the message through. It may be necessary to adjust the rate of speech, the vocabulary or the accent. Adjusting one's language towards that of your interlocutor is often necessary according to the following informant:

(1) It is a two-way thing, basically. Just as we [in Denmark] need to be better at including our guests and speak English [to non-Danes in the corporate headquarters], the Chinese also need to be better at speaking English, and the Americans need to think about their English, that they speak with an American accent we are able to understand.

-Mancorp_7, HR manager

Adjusting is here presented both as a matter of accommodating by switching languages (from Danish to English) and by adjusting the kind of English used. Interestingly, the interviewee explicitly mentions that also native English speakers need to consider adjusting their English.

In another example of informants adjusting their language towards the interlocutor, a Danish informant talks about communicating with Swedish colleagues in the Danish headquarters. As she describes it, 'They speak Swedish Danish, and we speak Danish' (Consult_3, Engineer). In this example accommodation is not a two-way thing. While the Swedes converge to the Danes by using 'Swedish Danish', the Danes who are on their home turf just keep on speaking Danish. In both cases, the adjustments - whether is it the kind of English used to cross language boundaries or the kind of Danish used to communicate in 
Denmark - are very much in line with the corporate language policies of using English to cross language boundaries, and the local languages in the local context. The second example reveals, however, that the majority language, in this case Danish, takes precedence over other languages, with majority speakers doing less of the accommodation work.

\section{Adjusting communication mode}

In some cases, it may not be enough to converge to the interlocutor e.g. by adjusting your accent. In these cases, employees may change the communication mode (Fjermestad, 2004):

(2) If I'm trying to communicate to a Chinese guy, and I cannot understand him [laughter] - it's not only me, also the rest of the guys in the department - [I tell the Chinese] 'please write it'.

-Mancorp_12, Consultant

In this example the employee encourages a switch from the oral mode to the written mode in order for him to understand a Chinese speaker of English. In addition to the 'traditional' modes of written and oral communication, the engineers at Consult also provide an example of using a visual mode to overcome a language barrier. They argue that while oral command of English is needed to negotiate contracts, at the 'technicians' level' a shift to the visual mode, in the form of sketches, can be helpful.

(3) Then we $[\ldots]$ may have to make a sketch in order to explain what the heck it is we mean, right.

-Consult_4, Engineer

By adjusting the communication mode, the employees in both of the above examples have to improvise and resort to ad hoc and informal solutions to overcome language barriers. Our findings thus reflect findings by Charles and Marschan-Piekkari (2002) and Harzing et al. (2011) who discuss how employees in multilingual organisations may find oral communication more challenging than written communication as well as observations made by Tenzer and Pudelko (2016) in their study of media choice in multilingual teams. Here, foreign language-induced cognitive load was found to be a 'powerful antecedent to media 
choice in virtual teamwork' (p. 445). While previous studies show that using 'lean media' such as email instead of face-to-face interaction or video calls had a positive impact on communication because 'lean media allowed individuals to reflect on their writing and correct mistakes and misspellings and thereby removed verbal cues that enhanced the possibility of misunderstandings' (Klitmøller and Lauring, 2013, p. 404), the same study also found that differences in communication styles lead to conflict and lack of knowledge sharing.

Our findings show that employees make use of their discretionary power when selecting the appropriate communication mode for multilingual communication. Here, the choice of communication mode can also be seen as a way of negotiating language use (cf. Gaibrois, 2015), thereby demonstrating the intricate relationship between language and communication practices in linguistically heterogeneous environments.

\section{Language tools}

Adjusting the accent or the mode of communication may be the first solution used to cross language boundaries. However, when this is not enough, employees have to find help elsewhere. Another way of crossing language barriers is to make use of various kinds of language tools, including dictionaries, term bases and machine translation. In addition to generic online dictionaries in Scandinavian languages and English, both Mancorp and Bankcorp have developed their own company-specific dictionaries which contain terms and expressions commonly used in the companies' internal communication, often referred to as 'company speak' in the literature (de Vecchi, 2012, 2014; Welch, Welch, and Piekkari, 2005). In Consult the employees report the use of term lists collected in individual projects.

In addition to these company-specific dictionaries or term lists, our interview data indicate that Google Translate is frequently used in all three companies. Some informants find Google Translate useful for providing them with a quick translation or language guidance right then and there. However, the quality of the translations is called into question:

(4) Usually it [Google Translate] is not that good, but it's only in emergencies, sometimes I can't reach the Finnish girl [a colleague in Finland], and you have to get something out really quickly, then you use that [Google Translate], but then she [the Finnish colleague] has to quality check it later.

-Bankcorp_9, Business partner 
As stated here, Google Translate is likely to produce lower quality texts than what other solutions would be offer, e.g. asking a colleague for help. Furthermore, there is also the risk that the use of Google Translate may compromise confidential information as information run through Google's system may be used by Google later on (Google, 2014²). This is something that the following informant is very aware of:

(5) I do not use Google Translate for any company related material, because we work with a lot of confidential information, and that is definitely a no-no.

-Bankcorp_8, Project manager

In the use of Google Translate we can see employees using their discretionary power to manage their jobs. Even though they are aware of problems using this tool, time pressure may cause them to resort to using it. Here we can see an example where employees have to improvise because of organisational pressures.

\section{Translation}

As previously mentioned, both Mancorp and Bankcorp have in-house translation departments where employees may consult a professional translator if needed. However, Bankcorp is the only company that offers this type of service for internal communication purposes. One key informant working in the Danish communication unit of Bankcorp elaborates:

(6) All communication that affects the employees must be available in the local languages. [...] As regards the local projects, for example something - it might be a Nordic initiative, but if it in any way goes out to the employees, and especially in the branch area, then it has to be in Danish [in Denmark].

-Bankcorp_4, Communication professional

\footnotetext{
${ }^{2}$ Google's Terms of use state that: 'When you upload, submit, store, send or receive content to or through our Services, you give Google (and those we work with) a worldwide license to use, host, store, reproduce, modify, create derivative works (such as those resulting from translations, adaptations or other changes we make so that your content works better with our Services), communicate, publish, publicly perform, publicly display and distribute such content.'
} 
At the same time it is evident from interview data that the use of Bankcorp's translation department comes with certain restrictions:

(7) We do sometimes discuss with them and ask them whether it really is the right thing to do, how important it is to get this translated, 'should we translate these 200 pages? What are you going to use them for?' [...], we don't just accept everything.

-Bankcorp_1, Translator

This quote illustrates that the employees in the translation department also use their discretionary power to determine what gets translated and what does not. As a consequence, requests for translations may turn into a power struggle with the translators having the right to accept or reject requests.

\section{Collegial language help}

In addition to the official translation departments, informants in Mancorp, Bankcorp and Consult also frequently rely on other colleagues in order to satisfy emergent language and communication needs:

(8) We would use our colleagues, ask each other. We know who are good at English, so we can draw on them and discuss with them what they think would work.

-Mancorp_3, Communication professional

Collegial help is also used to cross other language barriers, as this engineer explains:

(9) Consult_13: I have also talked to an Italian uh who had to speak English [...] And his English was very very bad, right.

Interviewer: Yes.

Consult_13: So I couldn't communicate at all [...] And so luckily we had an Italian or someone who could we had Linda who could help. Then she had to come in and be the interpreter in order for it to work out.

Interviewer: Even though she wasn't originally part of that conversation? 
Consult_13: Yes, she wasn't even on the project so I just came to her on my knees and asked for help, you know.

When the Danish engineer in this example had to negotiate with an Italian supplier over the phone, he had to bring in an Italian-speaking colleague to interpret. The excerpt reveals that his getting help happened mid-conversation when it was clear that he 'couldn't communicate at all' with the Italian. It is also clear that interpreting is not a part of Linda's regular duties, since the informant had to ask for her help 'on [his] knees'.

Even in organisations with an official translation department, collegial language help is very commonly used. As one Bankcorp employee explains:

(10) Well, in many cases it's sufficient to rely on our colleagues [to translate documentation written in foreign languages], but if it is something... you know, that really requires some official translation as such, sure, we can always order an official translator, but in my experience so far, that really hasn't been necessary.

-Bankcorp_8, Project manager

The informant here explains that he often comes across documents written in a foreign language, yet he still prefers asking a colleague for help rather than contacting the translation department in Bankcorp, which may be a cumbersome and time-consuming process (cf. Piekkari et al., 2013).

While previous research has also pointed to the importance of collegial help in overcoming language barriers, our results highlight the informal and ad hoc nature of most collegial help, as in the example in quote 9. In contrast with Mancorp and Bankcorp, Consult has no translation department or any other kind of language support. And translation to and from Italian is not covered in the language policy. Consequently, employees use their discretionary power to overcome this type of language barrier, e.g. by asking a colleague for help. From a critical point of view, this is problematic for several reasons. First of all, the lack of corporate language support leaves the responsibility for successful communication up to the individual employee, and delegates the burden of crossing language boundaries to the front-line level. 
Secondly, the ability to ask a colleague for help is largely dependent on one's individual network and social relationships in the workplace. Since employees' networks may themselves depend on their language competences (cf. Lauring and Tange, 2010), this ad hoc approach to collegial help can be problematic, particularly for employees without a large network in the company. Our findings also illustrate how asking for language help, informally or formally, may be seen as disempowering or cumbersome to the extent that people refrain from doing so. Despite the fact that two of the companies offer professional translation services in-house, respondents still regard the language skills of other front-line employees as more attractive and more easily accessible than those of the companies' professional translators. Also, as the above example with interpretation to and from Italian shows, asking a colleague for help means putting yourself in a supplicant position since you are asking them to do extra work as unofficial 'language nodes' (Marschan-Piekkari et al., 1999a), which could strain social relationships in the workplace (Feely and Harzing, 2003; Harzing and Feely, 2008; Piekkari et al., 2013, p. 777).

Thirdly, as evidenced by Nielsen (2015) and Vaara et al. (2005), the position of language node, i.e. the person helping out, is not always an enviable position either, as the extra language work may take the person away from their own busy schedule, or cause them to suffer from work overload as ‘ translation machines' (Vaara et al., 2005, p. 611).

\section{Avoiding language boundaries}

We have seen that employees in the three companies make use of a range of front-line communication practices to overcome language barriers, some in line with the language policy, some improvised ad hoc solutions where employees draw on their discretionary power to manage the situation. In other cases, however, employees choose not to cross the boundary in front of them; instead they choose to avoid it. As we will see, such choices are often the result of organisational pressures, such as a heavy workload or time pressure as described by Hughes and Condon (2016) and Meyers and Vorsanger (2007).

\section{Avoiding oral communication}

When meetings are held in English instead of a local language, it may have consequences for the interaction. Danish Consult employees say that they hold themselves back in meetings in English, participating less than when the meetings are in Danish: 
(11) We can see it in the management meetings. We also sit there saying nothing so there isn't a lot of dialogue. Yes, those who are good at English, they run the dialogue, but the rest of us we hold back a bit. It is only when it is really important.

-Consult_6, Head of department

Employees may also avoid foreign language interaction by prioritising interaction with colleagues with whom they share a mother tongue:

(12) Danish employees have a tendency to speak in Danish as soon as they find two Danishspeaking people, even if there are English-speaking people next to them.

-Mancorp_8, Senior vice president

In these examples it seems that the use of English itself as a type of organisational pressure combines with a lack of language resources and leads employees to use their discretionary power to either withdraw from interaction, or direct their attention to speakers of their own native language.

\section{Avoiding written communication}

Lauring and Klitmøller (2015, p. 47) define communication avoidance as 'the reluctance to engage in verbal interaction with other individuals'. In contrast with Lauring and Klitmøller, our findings show that avoidance occurs in written as well as oral communication. Lønsmann (2017), which also draws on data from Consult, finds that employees who work in a context where English is not relevant for their daily work are more likely to resist it, e.g. by deleting emails in English. Our analysis here shows a range of avoidance practices from deleting written information, over moving it down the list of priorities to just skimming the information. As one informant says about emails in English:

(13) Some things I skim, and others go into the 'we'll have a look at that when I finish some of the other things I have been pressed for' [pile].

-Consult_4, Engineer 
Interestingly, these avoidance practices are explicitly described as coping mechanisms to deal with time pressure and a heavy workload.

(14) And so what often happens is that when we get such a couple of pages of closelywritten English text, we don't have time to read it just then. You just don't get around to reading it.

- Consult_10, Engineer and project manager

Both informants describe here how they avoid reading information in English because of time pressure. Also other parts of the communication practices suggested in the language policy at Consult are managed with the discretionary power of the individual employees. The Consult language policy includes a line about practicing your English in order to become better. The informants in one of the focus groups argue, however, that the opportunities are simply not there:

(15) But, well, it is, it would seem weird if we went to [the client], and then we just plunged into speaking English to them. ... The situation just isn't there, and therefore it can seem forced if you say you just have to do it. Do what, you know? Do we have the time to do it? Will we be paid to practice?

- Consult_10, Engineer and project manager

This excerpt shows how the organisational context that employees work in does not always match the imagination of policy makers. While the informants would not mind practicing their English, their daily work does not provide them with opportunities to do so. In addition, the informant again raises the issue of time pressure by asking hypothetically if they would be allotted time to practice English. In Consult the rule is that every half hour of working time needs to be registered to a customer account so that the company can see how employees' time is spent. But there is no category in which to register time spent on practicing English or reading information in English. As such the organisational culture of strict time keeping clashes with expectations put forth in the language policy and forces employees to use their discretionary power, which in this case means that they avoid written communication in English as well as practicing. As described by Gilson (2015), the front-line employees do not 
deliberately try to oppose policy aims, but behave this way because the policies are incompatible with their work lives.

Employees responsible for communicating information to front-line employees also indicate that they are aware of these avoidance practices and adjust their language choice accordingly:

(16) Yes, we translate [information] for the intranet. We do it because we have noticed that it [the information] doesn't get read that much if it's only in English.

-Bankcorp_10, Consultant

As in the case with translations, we see that both language and communication experts and front-line employees use their discretionary power to interpret the language policies and deal with language barriers.

\section{Discussion}

Despite mainly English language policies in the three companies, our findings show that employees have to deal with a large number of different languages, and that they meet language boundaries both in internal and external communication, and in written and oral communication. In Table 3 we summarise these in terms of five main language-boundary interfaces.

\begin{tabular}{|l|l|l|}
\hline Language A & Language B & Example \\
\hline The local language & $\begin{array}{l}\text { English as a corporate } \\
\text { language }\end{array}$ & $\begin{array}{l}\text { A native Scandinavian-speaking } \\
\text { employee obtains information in } \\
\text { English }\end{array}$ \\
\hline The local language & $\begin{array}{l}\text { Other Scandinavian } \\
\text { language }\end{array}$ & $\begin{array}{l}\text { A native Scandinavian-speaking } \\
\text { employee communicates with a } \\
\text { speaker of another Scandinavian } \\
\text { language both using their mother } \\
\text { tongue }\end{array}$ \\
\hline The local language & Other foreign languages & $\begin{array}{l}\text { A native Scandinavian-speaking } \\
\text { employee communicates with a } \\
\text { speaker of a foreign language, e.g. } \\
\text { German, in that foreign language }\end{array}$ \\
\hline English used as a & Native-speaker English & A native Scandinavian-speaking \\
\hline
\end{tabular}




\begin{tabular}{|l|l|l|}
\hline lingua franca & & $\begin{array}{l}\text { employee communicates with a } \\
\text { British English speaker in English }\end{array}$ \\
\hline $\begin{array}{l}\text { English used as a } \\
\text { lingua franca }\end{array}$ & $\begin{array}{l}\text { English used as a lingua } \\
\text { franca }\end{array}$ & $\begin{array}{l}\text { Two non-native English-speaking } \\
\text { employees communicate in English }\end{array}$ \\
\hline
\end{tabular}

Table 3 Language-boundary interfaces

These language-boundary interfaces emphasise the fact that corporate language policies often do not cover the complexity of language issues faced by front-line employees. Because the linguistic reality is much more diverse than the language policies suggest, front-line employees in the three companies have to resort to a wide range of ad hoc and informal communication practices, such as asking a colleague for help interpreting a phone call in Italian or using Google Translate to understand an email in another Nordic language.

The concept of discretionary power predicts that front-line employees are likely to use their discretion when policies are incompatible with everyday demands of the job. Our analysis shows how this applies also to the language choices made by employees in their complex multilingual work environment where employees rely on a range of practices to overcome language barriers, and often use their discretionary power to diverge from the corporate language policies. In contrast with the frequent use of ad hoc practices, corporatelevel language support in the form of company term lists or translation services is only used sporadically. Hence, employees' exercise of discretionary power in relation to language and communication practices should be seen as a way of adjusting to the context and the organisational demands they are exposed to (Maynard-Moody and Portillo, 2011).

Withdrawal and avoidance practices have previously been coupled with low English fluency levels (Barner-Rasmussen and Björkman, 2007; Neeley, 2013; Neeley et al., 2012). Despite the fact that the Scandinavian countries consistently rank at the top in tests that give an indication of a country's average level of English language skills (ETS, 2014), our results indicate that English may still present a problem for some employees. Our findings show that this behaviour is found among Danish consultants, including managers, who will refrain from participating in meetings in English unless it is critical. That English is also a barrier in countries with high average English skills and among highly educated employees is an important finding, especially in the face of hegemonic language ideologies which proclaim English the 'natural' language of international collaboration (Kraft and Lønsmann, fc.; 
Lønsmann, 2015) and disadvantage employees who lack English skills (Boussebaa and Brown, 2016; Tietze and Dick, 2012).

Evidence of avoidance practices is particularly interesting in an investigation of frontline employees' agency. While employees on the one hand use their agency as discretionary power when they choose not to contribute in meetings in English or choose not to read information in English, on the other hand this use of discretionary power actually functions to disempower these same employees who through these avoidance practices remove themselves from decision-making and knowledge-sharing.

\section{Conclusion}

The present study emphasises the role and agency of front-line employees by providing a bottom-up perspective on language policy in international business. Our findings demonstrate that front-line employees play a vital part in carrying out the official language policy of the organisation (cf. Lipsky, 1980, 2010). These findings call attention to the importance of frontline employees' communication practices in corporate language management and language policy implementation.

This article contributes to the existing language-sensitive literature in international business and management in three ways. First of all, by providing a front-line perspective on language policy implementation, our findings call attention to the importance of front-line agency and discretion when it comes to everyday language choices in linguistically diverse workplaces. This focus on practices used by employees to cross language boundaries gives emphasis to the individuals who ultimately make up large, multinational organisations, thereby offering a counterweight to the studies focusing on top-down language management. We find that 'discretionary power' is a useful term to introduce to the international business and management literature, as it captures the dynamics of language policy implementation at the front-line level. By showing how front-line employees' communication practices are influenced by organisational structures and at the same time transcend these structures, one of the contributions of our study is to offer conceptual clarity on the role of front-line employees in corporate language management.

Secondly, the article explores implications for employees who are left to manage language issues through front-line communication practices, including implications for knowledge-sharing and decision-making in the organisation. The present study thus 
emphasises the human resource aspect of the management of employees' language practices and relates this to the broader picture of international management. Our findings show that employees often have to depend on ad hoc and informal solutions in situations where they have to cross language boundaries, which demonstrates that language polices which are not based on actual language needs in the organisation fail to support employees in their daily communication tasks. It also demonstrates that corporate language policies which do not support employees tend not to be followed. This suggests that in order to facilitate communication in linguistically diverse organisations, language policies should be based on pragmatic considerations allowing for some degree of freedom in terms of language choice. Ideally, language policies should be based on actual language needs of front-line employees.

Finally, by acknowledging that language management takes place in different ways at different organisational levels, the article complements existing research where much attention is given to English lingua franca policies, and offers insights into how corporate language management may be executed in practice. The importance of informal practices for successful language-boundary crossing at the front-line level, such as employees' collegial network, suggests that language management tools like language training or selective recruitment of language-skilled personnel may benefit a potentially larger portion of the overall workforce than service solutions like in-house translation departments. Across our data sample, employees tend to prefer on-the-spot solutions, even if it compromises the quality of their communication, as in the case of Google Translate. This finding indicates that employees will only make use of top-down language management initiatives if they are able to satisfy emergent language needs in a timely and efficient manner.

We should emphasise that this is a study which only includes MNCs headquartered in Scandinavian countries, i.e. Denmark and Sweden, where corporate language policies tend to be more flexible and adaptive than in other parts of Europe (Piekkari and Tietze, 2012, p. 561). This is a potential limitation of the study in the sense that employees may feel less inclined to follow a loosely formulated corporate language policy. Future research could consider front-line communication practices under strictly regulating language policies, and the extent to which these policies support or restrict language-boundary crossing among employees. We would also like to encourage the use of observational data in future studies, such as long-term participant observation and other ethnographic research methods. 


\section{Acknowledgements}

The authors would like to thank the editor and the two anonymous reviewers for their constructive comments and suggestions which greatly improved the quality of this paper. We would also like to thank the GEM\&L community for valuable feedback on an earlier version of this paper presented at the 10th International GEM\&L Conference, 2016.

\section{References}

Andersen, H., and Rasmussen, E.S. (2004) 'The role of language skills in corporate communication', Corporate Communication: An International Journal, Vol. 9 No. 3, pp.231-242.

Angouri, J., and Miglbauer, M. (2014) 'A And then we summarise in English for the others': The lived experience of the multilingual workplace', Multilingua, Vol. 33 No. 1-2, pp.147-172.

Barner-Rasmussen, W., and Björkman, I. (2007) 'Language fluency, socialization and interunit relationships in Chinese and Finnish subsidiaries', Management and Organization Review, Vol. 3 No. 1, pp.105-128.

Björkman, I., Barner-Rasmussen, W., and Li, L. (2004) 'Managing knowledge transfer in MNCs: The impact of headquarters control mechanisms', Journal of International Business Studies, Vol. 35 No. 5, pp.443-455.

Björkman, I., Barner-Rasmussen, W., and Vaara, E. (2010) 'Towards crossvergence, microlevel approaches and critical perspectives: Introduction to the special issue on new perspectives on international management research', Scandinavian Journal of Management, Vol. 26 No. 4, pp.417-420.

Boussebaa, M., and Brown, A. D. (2017) 'Englishization, identity regulation and imperialism', Organization Studies, Vol. 38, No. 1, pp.7-29.

Boussebaa, M., Sinha, S., and Gabriel, Y. (2014) 'Englishization in offshore call centers: a postcolonial perspective', Journal of International Business Studies, Vol. 45, No. 9, pp.1152-1169.

Charles, M., and Marschan-Piekkari, R. (2002) 'Language training for enhanced horizontal communication: A challenge for MNCs', Business Communication Quarterly, Vol. 65 No. 2, pp.9-29. 
Confederation of Danish Industry (DI) (2013, unpublished) Survey on corporate language policies among DI's member organisations. Data retrieved from DI, 24.04.2015.

Corbin, J., and Strauss, A. (1990) Grounded theory research: Procedures, canons, and evaluative criteria, Qualitative Sociology, Vol. 13 No. 1, pp.3-21.

Corbin, J., and Strauss, A. (2008) Basics of Qualitative Research. Techniques and Procedures for Developing Grounded Theory, Sage Publications Ltd, London.

Corley, K.G., and Gioia, D.A. (2004) 'Identity ambiguity and change in the wake of a corporate spin-off', Administrative Science Quarterly, Vol. 49 No. 2, pp.173-208.

Davis, K.C. (1969) Discretionary Justice: A Preliminary Inquiry, Louisiana State University Press, Baton Rouge.

De Vecchi, D. (2012) 'What do 'they' mean by that? The (hidden) role of language in a merger', LSP Journal, Vol. 3 No. 2, pp.71-85.

De Vecchi, D. (2014) 'Company-speak: an inside perspective on corporate language', Global Business and Organizational Excellence, Vol. 33 No. 2, pp.64-74.

Duchêne, A. (2009) 'Marketing, management and performance: Multilingualism as commodity in a tourism call centre', Language policy, Vol. 8 No. 1, pp.27-50.

Durose, C. (2009) 'Front-line workers and 'local knowledge': neighbourhood stories in contemporary UK local governance', Public Administration, Vol. 87 No. 1, pp.35-49.

ETS. (2014) Test and score data summary for TOEFL iBT Tests. [online] http://www.ets.org/s/toefl/pdf/94227_unlweb.pdf (Accessed 13 April 2016)

Feely, A.J., and Harzing, A.W. (2003) 'Language management in multinational companies', Cross Cultural Management: An International Journal, Vol. 10 No. 2, pp.37-52.

Fjermestad, J. (2004) 'An analysis of communication mode in group support systems research', Decision Support Systems, Vol. 37 No. 2, pp.239-263.

Fredriksson, R., Barner-Rasmussen, W., and Piekkari, R. (2006) 'The multinational corporation as a multilingual organization: the notion of a common corporate language', Corporate Communications: An International Journal, Vol. 11 No. 4, pp.406-423.

Gaibrois, C. (2015) Power at Work: The Discursive Construction of Power Relations in Multilingual Organizations. Unpublished PhD thesis, University of St. Gallen, St. Gallen, Switzerland. 
Giddens, A. (1991) Modernity and Self-Identity: Self and Society in the Late Modern Age, Stanford, Stanford University Press.

Giles, H., and Coupland, N. (1991) 'Language attitudes: discursive, contextual, and gerontological considerations', in Reynolds, A.G. (Ed.), Bilingualism, Multiculturalism, and Second Language Learning, Lawrence Erlbaum Associations, Inc, New York, pp.21-42.

Gilson, L.L. (2015) 'Michael Lipsky, street-level bureaucracy: dilemmas of the individual in public service', in Lodge, M., Page, E.C., and Balla, S.J. (Eds.), The Oxford Handbook of Classics in Public Policy and Administration, Oxford University Press, Oxford, pp.383-404.

Google. (2014). Google terms of service. [online] http://www.google.com/intl/en/policies/terms/ (Accessed 13 April 2016).

Harzing, A.W., and Feely, A.J. (2008) 'The language barrier and its implications for HQsubsidiary relationships', Cross Cultural Management: An International Journal, Vol. 15 No. 1, pp.49-61.

Harzing, A-W., Köster, K., and Magner, U. (2011) 'Babel in business: the language barrier and its solutions in the HQ-subsidiary relationship', Journal of World Business, Vol. 46 No. 3, pp.279-287.

Harzing, A-W., and Pudelko, M. (2013) Language competencies, policies and practices in multinational corporations: A comprehensive review and comparison of Anglophone, Asian, Continental European and Nordic MNCs, Journal of World Business Vol. 48 No. 1, pp.87-97.

Harzing, A.W., and Pudelko, M. (2014) 'Hablas vielleicht un peu la mia language? A comprehensive overview of the tole of language differences in headquarters-subsidiary communication', The International Journal of Human Resource Management, Vol. 25 No. 5, pp.696-717.

Hughes, A., and Condon, L. (2016) 'Street-level bureaucracy and policy implementation in community public health nursing: a qualitative study of the experiences of student and novice health visitors', Primary Health Care Research \& Development, Vol. 17 No. 6, pp. 586-598. 
Klitmøller, A., and Lauring, J. (2013) 'When global virtual teams share knowledge: Media richness, cultural difference and language commonality', Journal of World Business, Vol. 48 No. 3, pp.398-406.

Kraft, K., and Lønsmann, D. Forthcoming. 'A language ideological landscape: the complex map in international companies in Denmark', in Sherman, T. and Nekvapil, J. (Eds.) English in Business and Commerce: Interactions and policies. Mouton De Gruyter.

Kumar, N., Stern, L. W., and Anderson, J.C. (1993) 'Conducting interorganizational research using key informants', Academy of Management, Vol. 36 No. 6, pp.1633-1651.

Lauring, J., and Klitmøller, A. (2015) 'Corporate language-based communication avoidance in MNCs: a multi-sited ethnography approach', Journal of World Business, Vol. 50 No. 1, pp.46-55.

Lauring, J., and Tange, H. (2010) 'International language management: contained or dilute communication', European Journal of International Management, Vol. 4 No. 4, pp.317-322.

Lipsky, M. (1980) Street-Level Bureaucracy: Dilemmas of the Individual in Public Services, New York, Russell Sage Foundation.

Lipsky, M. (2010) Street-Level Bureaucracy, 30th Anniversay Expanded Edition: Dilemmas of the Individual in Public Services, New York, Russell Sage Foundation.

Lønsmann, D. (2011) English as a Corporate Language. Language Choice and Language Ideologies in an International Company in Denmark. Unpublished PhD thesis, Roskilde University, Roskilde, Denmark.

Lønsmann, D. (2015) 'Language ideologies in a Danish company with English as a corporate language: 'It has to be English', Journal of Multilingual and Multicultural Development, Vol. 36 No. 4, pp.339-356.

Lønsmann, D. (2017) 'Embrace it or resist it? Employees' reception of corporate language policies', International Journal of Cross Cultural Management, Vol. 17 No. 1, pp.101123.

Marschan-Piekkari, R., Welch, D., and Welch, L. (1999a) 'In the shadow: The impact of language on structure, power and communication in the multinational', International Business Review, Vol. 8 No. 4, pp.421-440 
Marschan-Piekkari, R., Welch, D., and Welch, L. (1999b) 'Adopting a common corporate language: IHRM implications', The International Journal of Human Resource Management, Vol. 10 No. 3, pp.377-390.

Maxwell, J.A. (2012) A Realist Approach for Qualitative Research, Sage Publications Ltd, London.

Maynard-Moody, S., and Portillo, S. (2010) 'Street-level bureaucracy theory' in Durant, R.F. (Ed.), The Oxford Handbook of American Bureaucracy, Oxford University Press, Oxford, pp. 252-277.

Meyers, M.K., and Vorsanger, S. (2007) 'Street-level bureaucrats and the implementation of public policy', in Peters, B.G and Pierre, J. (Eds.), Handbook of Public Administration: Concise Paperback Edition, Sage Publications, London, pp.153-164.

Neeley, T.B. (2013) 'Language matters: Status loss and achieved status distinction in global Organization', Organizational Science, Vol. 24 No. 4, pp.476-497.

Neeley, T.B., Hinds, P.M., and Cramton, C.D. (2012) 'The (un)hidden turmoil of language in global collaboration', Organizational Dynamics, Vol. 41 No. 3, pp.236-244.

Nielsen, L. (2015) Language Policy in the Danish Ministry of Foreign Affairs. Unpublished Master's thesis, Copenhagen Business School, Frederiksberg, Denmark.

Patton, M.Q. (2002) Qualitative Research and Evaluation Methods, 3rd ed., Sage Publications Ltd, London.

Piekkari, R., and Tietze, S. (2011) 'A world of languages: implications for international management research and practice', Journal of World Business, Vol. 46 No. 3, pp.267269.

Piekkari, R., and Tietze, S. (2012) 'Language and international human resource management', in Stahl, G.K. and Björkman, I. (Eds.), Handbook of Research in International Human Resource Management, 2nd ed., Edward Elgar, Cheltenham, pp.549-565.

Piekkari, R., Welch, D.E. and Welch, L.S. (2014) Language in International Business: The Multilingual Reality of Global Business Expansion, Edward Elgar, Cheltenham.

Piekkari, R., Welch, D.E, Welch, L.S., Peltonen, J.P., and Vesa, T. (2013) 'Translation behaviour: an exploratory study within a service multinational', International Business Review, Vol. 22 No. 5, pp.771-783. 
Sanden, G.R. (2015) Language Strategies in Multinational Corporations. A Cross-sector Study of Financial Service Companies and Manufacturing Companies. Unpublished PhD thesis, Copenhagen Business School, Frederiksberg, Denmark.

Sanden, G.R. (2016) 'Language management x 3: a theory, a sub-concept, and a business strategy tool', Applied Linguistics, Vol. 37 No. 4, pp.520-535.

Sayer, A. (1992) Method in Social Science. A Realist Approach, Routledge, London.

Sevä, M. and Jagers, S.C. (2013) 'Inspecting environmental management from within: the role of street-level bureaucrats in environmental policy implementation', Journal of Environmental Management, Vol. 128 No. 15, pp.1060-1070.

Shachaf, P. (2008) 'Cultural diversity and information and communication technology impacts on global virtual teams: an exploratory study', Information and Management, Vol. 45 No. 2, pp.131-142.

Śliwa, M. and Johansson, M. (2014) 'How non-native English-speaking staff are evaluated in linguistically diverse organizations: A sociolinguistic perspective', Journal of International Business Studies, Vol. 45 No 9, pp.1133-1151.

Spolsky, B. (2009) Language Management, Cambridge University Press, Cambridge.

Strauss, A. (1987) Qualitative Analysis for Social Scientists, Cambridge University Press, Cambridge.

Strauss, A., and Corbin, J. (1998) Basics of Qualitative Research. Grounded Theory Procedures and techniques, Sage Publications Ltd, Newbury Park.

Symon, G., and Cassell, C. (2012) Qualitative Organizational Research. Core Methods and Current Challenges, Sage Publications Ltd, London.

Tenzer, H., and Pudelko, M. (2016) 'Media choice in multilingual virtual teams', Journal of International Business Studies, Vol. 47 No. 4, pp.427-452.

Tietze, S. (2010) 'International managers as translators', European Journal of International Management, Vol. 4 No. 1/2, pp.184-199.

Tietze, S. and Dick, P. (2012)'The victorious English language: Hegemonic practices in the management academy', Journal of Management Inquiry, Vol. 22, No. 1, pp.122-134.

Vaara, E., Tienari, J., Piekkari, R., and Säntti, R. (2005) 'Language and the circuits of power in a merging multinational corporation', Journal of Management Studies, Vol. 42, No. 3, pp.595-623. 
Walker, R.M., and Enticott, G. (2004) 'Using multiple informants in public administration: revisiting the managerial values and action debates', Methods and Epistemology, Vol. 14 No. 3, pp.417-434.

Welch, C., Piekkari, P., Plakoyiannaki, E., and Paavilainen-Mäntymäki, E. (2011) 'Theorising from case studies: Towards a pluralist future for international business research', Journal of International Business Studies, Vol. 42 No. 5, pp.740-762.

Welch, D., Welch, L., and Piekkari, R. (2001) 'The persistent impact of language on global operations', Prometheus, Vol. 19 No. 3, pp.193-209.

Welch, D., Welch, L., and Piekkari, R. (2005) 'Speaking in tongues: the importance of language in international management processes', International Studies of Management and Organization, Vol. 35 No. 1, pp.10-27. 


\section{Appendix I: Data collection}

\begin{tabular}{|l|l|l|l|l|}
\hline $\begin{array}{l}\text { Informant } \\
\text { ID }\end{array}$ & Job title & $\begin{array}{l}\text { Interview } \\
\text { language }\end{array}$ & $\begin{array}{l}\text { Informants' } \\
\text { L1 }\end{array}$ & $\begin{array}{l}\text { Date and duration of } \\
\text { interviews/meetings }\end{array}$ \\
\hline Mancorp_1 & $\begin{array}{l}\text { Communication } \\
\text { professional }\end{array}$ & Danish & Danish & $20.09 .13: 45 \mathrm{~min}$ \\
\hline Mancorp_2 & $\begin{array}{l}\text { Communication } \\
\text { professional }\end{array}$ & Danish & Danish & $19.09 .13: 70 \mathrm{~min}$ \\
\hline Mancorp_3 & $\begin{array}{l}\text { Communication } \\
\text { professional }\end{array}$ & Danish & Danish & $19.09 .13: 55$ min \\
\hline Mancorp_4 & $\begin{array}{l}\text { Communication } \\
\text { professional }\end{array}$ & Danish & Danish & $19.09 .13: 60$ min \\
\hline Mancorp_5 & Translator & Danish & Danish & $18.10 .13: 50$ min (phone) \\
\hline Mancorp_6 & Personal assistant & Danish & Danish & $23.10 .13: 40$ min (phone) \\
\hline Mancorp_7 & HR manager & Danish & Danish & $20.09 .13: 55$ min \\
\hline Mancorp_8 & Senior vice president & English & Swedish & $31.10 .13: 35$ min (phone) \\
\hline Mancorp_9 & Project consultant & Danish & Danish & $19.09 .13: 60$ min \\
\hline Mancorp_10 & Project manager & English & Hungarian & $20.09 .13: 60$ min \\
\hline Mancorp_11 & Student assistant & Danish & Danish & $19.09 .13: 45$ min \\
\hline Mancorp_12 & Consultant & English & Spanish & $31.10 .13: 55$ min \\
\hline & \multicolumn{3}{|l|}{ Total interview time: 10 hours and 30 min } \\
\hline
\end{tabular}

Overview of informants Mancorp

\begin{tabular}{|c|c|c|c|c|}
\hline $\begin{array}{l}\text { Informant } \\
\text { ID }\end{array}$ & Job title & $\begin{array}{l}\text { Interview } \\
\text { language }\end{array}$ & $\begin{array}{l}\text { Informants' } \\
\text { L1 }\end{array}$ & $\begin{array}{l}\text { Date and duration of } \\
\text { interviews/meetings }\end{array}$ \\
\hline \multirow[t]{2}{*}{ Bankcorp_1 } & \multirow[t]{2}{*}{ Translator } & \multirow[t]{2}{*}{ Danish } & \multirow[t]{2}{*}{ Danish } & $31.08 .12: 90 \mathrm{~min}$ \\
\hline & & & & $07.05 .13: 90 \mathrm{~min}$ \\
\hline Bankcorp_2 & Translator & Swedish & Swedish & $07.11 .13: 55 \mathrm{~min}$ \\
\hline Bankcorp_3 & Translator & Danish & Danish & 16.05.13: $90 \mathrm{~min}$ \\
\hline Bankcorp_4 & $\begin{array}{l}\text { Communication } \\
\text { professional }\end{array}$ & Danish & Danish & 21.03.14: $45 \min$ (phone) \\
\hline Bankcorp_5 & $\begin{array}{l}\text { Communication } \\
\text { professional }\end{array}$ & Danish & Danish & $23.10 .13: 50 \mathrm{~min}$ \\
\hline Bankcorp_6 & HR manager & English & Swedish & $07.11 .13: 60 \mathrm{~min}$ \\
\hline Bankcorp 7 & HR manager & English & Swedish & $08.11 .13: 45 \mathrm{~min}$ \\
\hline Bankcorp_ 8 & Project manager & English & Turkish & 11.12.13: $35 \mathrm{~min}$ (phone) \\
\hline Bankcorp_9 & Business partner & English & Swedish & 08.11.13: $80 \mathrm{~min}$ \\
\hline Bankcorp_10 & Consultant & Swedish & $\begin{array}{l}\text { Swedish/ } \\
\text { English } \\
\text { (American) }\end{array}$ & $07.11 .13: 55 \mathrm{~min}$ \\
\hline
\end{tabular}

Overview of informants Bankcorp 


\begin{tabular}{|c|c|c|c|c|}
\hline $\begin{array}{l}\text { Informant } \\
\text { ID }\end{array}$ & Job title & $\begin{array}{l}\text { Interview } \\
\text { language }\end{array}$ & $\begin{array}{l}\text { Informants' } \\
\text { L1 }\end{array}$ & $\begin{array}{l}\text { Date and duration } \\
\text { of interviews }\end{array}$ \\
\hline $\begin{array}{l}\text { Consult_1 } \\
\text { Consult_2 } \\
\text { Consult_3 } \\
\text { Consult_4 } \\
\text { Consult 5 }\end{array}$ & $\begin{array}{l}\text { Project manager/engineer } \\
\text { Electrician } \\
\text { Engineer } \\
\text { Engineer } \\
\text { Project manager }\end{array}$ & Danish & $\begin{array}{l}\text { Danish } \\
\text { Danish } \\
\text { Danish } \\
\text { Danish } \\
\text { Danish }\end{array}$ & 11.03.15: $109 \mathrm{~min}$ \\
\hline $\begin{array}{l}\text { Consult_6 } \\
\text { Consult_7 } \\
\text { Consult_8 } \\
\text { Consult_9 } \\
\text { Consult_10 }\end{array}$ & $\begin{array}{l}\text { Head of department } \\
\text { Engineer/project manager } \\
\text { Engineer } \\
\text { Project manager } \\
\text { Engineer/project manager }\end{array}$ & Danish & $\begin{array}{l}\text { Danish } \\
\text { Danish } \\
\text { Tamil } \\
\text { Danish } \\
\text { Danish }\end{array}$ & 23.03.15: $91 \mathrm{~min}$ \\
\hline $\begin{array}{l}\text { Consult_11 } \\
\text { Consult_12 } \\
\text { Consult_13 } \\
\text { Consult_14 } \\
\text { Consult_15 }\end{array}$ & $\begin{array}{l}\text { Engineer } \\
\text { Senior engineer } \\
\text { Engineer } \\
\text { Technical assistant } \\
\text { Engineer }\end{array}$ & Danish & $\begin{array}{l}\text { Danish } \\
\text { Danish } \\
\text { Danish } \\
\text { Danish } \\
\text { Danish }\end{array}$ & 08.04.15: $87 \mathrm{~min}$ \\
\hline & & & & $\begin{array}{l}\text { Total interview } \\
\text { time: } 4 \text { hours and } \\
47 \mathrm{~min}\end{array}$ \\
\hline
\end{tabular}

Overview of informants Consult

\begin{tabular}{|l|l|l|l|}
\hline & Mancorp & Bankcorp & Consult \\
\hline $\begin{array}{l}\text { Internal } \\
\text { material }\end{array}$ & $\begin{array}{l}\text {-Language policy, English } \\
\text { and Danish language } \\
\text { versions } \\
\text {-Group policies, 2001 } \\
\text { version } \\
\text {-CSR brochures, incl. } \\
\text { 'Code of conduct - how } \\
\text { we practice it'; 'Bring } \\
\text { clean water to Vietnam'; } \\
\text { 'The CEO water mandate. } \\
\text { Communication on } \\
\text { progress, water report } \\
\text { 2012' }\end{array}$ & $\begin{array}{l}\text {-Language policy (print- } \\
\text { outs from the company's } \\
\text { intranet), English and } \\
\text { Danish language version } \\
\text {-Business case for future } \\
\text { handling of translation, } \\
\text { from 2000 } \\
\text {-Recruitment policy incl. } \\
\text { guide to the company's } \\
\text { recruitment policy' and } \\
\text { example of job } \\
\text { specification }\end{array}$ & $\begin{array}{l}\text {-Language policy, English } \\
\text { and Danish language } \\
\text {-PowerPoint presentation: } \\
\text { Upgrading our language } \\
\text { skills } \\
\text {-PowerPoint presentation: } \\
\text {-PowerPoint presentation: } \\
\text { 'IT survey. Score break- } \\
\text { down for country' (survey } \\
\text {-PowerPoint presentation: } \\
\text { Key findings (of an } \\
\text { internal studies of } \\
\text { language use) } \\
\text { - Intranet news item: } \\
\text { Introduction of language } \\
\text { strategy }\end{array}$ \\
\hline
\end{tabular}




\begin{tabular}{|c|c|c|c|}
\hline $\begin{array}{l}\text { Publicly } \\
\text { available } \\
\text { material }\end{array}$ & $\begin{array}{l}\text {-Group policies, } 2014 \\
\text { version } \\
\text {-Company magazine, } \\
\text { available in Danish and } \\
\text { English language versions } \\
\text {-Annual reports 2001-2014 } \\
\text {-Information about the } \\
\text { company's workforce } \\
\text {-Information about the } \\
\text { company's history and } \\
\text { background }\end{array}$ & $\begin{array}{l}\text {-PowerPoint presentation } \\
\text { on English as a corporate } \\
\text { language } \\
\text {-Annual reports } 1998-2014 \\
\text {-Information about the } \\
\text { company's history and } \\
\text { background }\end{array}$ & $\begin{array}{l}\text { - Information about the } \\
\text { company's workforce } \\
\text { - Information about the } \\
\text { company's history and } \\
\text { background }\end{array}$ \\
\hline
\end{tabular}

Overview of written documentation 


\section{Appendix II: Original language quotes}

(1) Dybest set er det jo en tovejs ting. Lige så vel som vi skal blive bedre til at tage imod vores gæster og tale det andet sprog og tale engelsk, det skal kineserne også, de skal også blive bedre til at tale engelsk, og amerikanerne skal øve sig i, at de taler et amerikansk, som vi kan forstå.

(2) English in the original

(3) Så kan det godt være [...] vi bliver nødt til at lave en øh skitse for at forklare, hvad fanden det er, vi mener, ik.

(4) English in the original

(5) English in the original

(6) Al kommunikation der vedrører medarbejdere skal være på lokalsprog [...] I forhold til lokale projekter, for eksempel i noget, det kan godt være et nordisk initiativ, men hvis det på nogen måde går ud til medarbejdere, og i særdeleshed til filialområdet, skal det altid være på dansk.

(7) Vi diskuterer jo også nogle gange med dem, og siger men er det virkelig det rigtige, er det vigtigt at få det her oversat, altså skal vi oversætte de her 200 sider? Hvad skal I bruge dem til? [...] Vi tager ikke alt bare ind.

(8) Der bruger vi så, internt, kollegaer, indimellem bruger vi hinanden. Vi ved, hvem der er stærkest til engelsk, og så kan vi jo trække på dem, og så snakker vi os frem til noget vi tror på fungerer.

(9)

Consult_13: Jeg har også snakket sammen med en italiener øh som også skulle snakke engelsk. [...] Og han var rigtig rigtig dårlig til engelsk ik

Interviewer: Ja.

Consult_13: Og så kunne jeg slet ikke kommunikere. [...] Og så heldigvis så havde vi en italiensk, eller en der kunne, Linda der kunne hjælpe. Sså måtte hun ind og så sidde og være tolk for at det gik godt.

Interviewer: Selvom hun egentlig ikke var en del af den samtale? 
Consult_13: Ja, hun var slet ikke på projektet, så jeg kom bare kravlende og spurgte om hjælp, ik.

(10) English in the original

(11) Vi kan jo se det på ledermøderne. Vi sidder jo også og siger ingenting, så der er ikke meget dialog. Jo, dem der er gode til engelsk, de kører med dialogen, men os andre vi holder os da lidt tilbage. Det er da kun, når det er rigtig vigtigt.

(12) English in the original

(13) Noget bliver skimmet, og andet ryger over i den der 'dem ser vi på, når jeg er færdig med nogle af de andre ting, jeg er blevet rykket for' [bunken].

(14) Og derfor sker der ofte det, at når vi får sådan et par sider tæt skrevet på engelsk, at det har vi ikke lige tid til at læse. Det får man ikke lige læst.

(15) Jamen, altså, altså det er jo, det ville jo virke underligt, hvis vi tog hen i forsyningen, og så kastede vi os bare over og snakkede engelsk til dem. ... Situationen er der så bare ikke, og derfor kan det virke kunstigt, hvis man siger, man skal bare i gang. I gang med hvad altså? Har vi tid til at gøre det? Får vi betalt, at vi skal sidde og øve os?

(16) Ja, för intranätet översätter vi. Det är för vi har märkt att det blir inte läst lika mycke om det bara är på engelska 